\title{
26. BIOSTRATIGRAPHY OF THE MESOZOIC AND PALEOGENE PELAGIC SEDIMENTS OF THE CAMPECHE EMBANKMENT AREA
}

\author{
Blake Woodbury McNeely, Shell Oil Company, Metairie, Louisiana
}

\section{GENERAL}

During Leg 10, holes were drilled and cored at thirteen sites in the Gulf of Mexico. This study is concerned with the biostratigraphy of the Mesozoic and the Paleogene sections in the Campeche Embankment area (Figure 1). Mesozoic or Paleogene sediments were penetrated only at Sites 86, 94, 95 (on the Campeche Embankment), 96 (in the Catoche Tongue), and 97 (in the Florida Strait). Hole $85 \mathrm{~A}$ is also discussed because the reworked Mesozoic planktonics observed in this hole may contribute to an understanding of the genesis of the deep Gulf of Mexico basin.

Late Cretaceous planktonic foraminifera were recovered at Sites 95 and 97. At Sites 86 and 94, the entire late Cretaceous (Cenomanian-Maestrichtian) section is apparently absent. A probable hiatus at Site 97 was recognized where early Eocene pelagic sediments overlie pelagic sediments of the early Cenomanian. Late Cenomanian-Coniacian in situ sediments were not cored during Leg 10.

Paleogene planktonic foraminifera were encountered at five sites on the Campeche Embankment, in the Catoche Tongue, and in the Florida Strait. Very good to excellent preservation of the foraminiferal tests was noted in mosts of the samples examined. Two hiatuses, one in the Paleocene and one in the middle Eocene, account for the absence of at least four planktonic foraminiferal zones.

Mesozoic-Paleogene samples examined were for the most part free of reworked foraminifera. Notable exceptions were the late Cretaceous and the early Paleocene samples from Sites 95 and 97. Core 12 from Site 95 contains late Cretaceous planktonics reworked into the early Paleocene, and Core 13 shows Santonian-early Maestrichtian planktonics reworked into middle-late Maestrichtian sediments. Rare reworked early Santonian planktonics are present in the probably late Santonian sediments from Core 15. Late Albian shallow-water limestone rubble dominates the washed residue of early Cenomanian pelagic deposits from Site 97 (Cores 6-10).

The depositional environment of the Paleogene and late Cretaceous biogenic sediments has been determined as bathyal. Inasmuch as calcareous foraminiferal tests are excellently preserved and are abundant in practically all of the samples examined, it seems certain that during deposition this area was not below the calcium carbonate compensation depth.

It has been suggested that a relationship may exist between the dominance of either keeled or nonkeeled planktonic foraminifera and warm or cold surface water temperatures (Bandy 1964). Applying this hypothesis, the late Paleocene through early middle Eocene and most of the late Cretaceous probably reflect subtropical to tropical surface paleotemperatures, inasmuch as keeled forms are abundant in these sediments. Early Paleocene and Oligocene faunas, where keeled forms are absent, suggest periods of cooler temperatures.

A small percentage of all faunas examined is of benthonic origin, although in some instances the benthonic percentage is rather high (for example, Site 95, Core 13, Section 2). Most of the benthonic foraminifera described from outcrops of Gulf Coast Paleogene and Mesozoic neritopelagic sediments are absent. In situ shallow-water carbonates of probable late Albian age recovered from Sites 86,94 , and 95 are the only sediments examined in which no planktonic foraminifera are present.

In the following discussion, sediments recovered on Leg 10 are considered in order from the oldest to the youngest. The Paleogene is discussed only in a general way. Because of the bathyal nature of all of these sediments, little interpretive effort is required. Table 1 gives the Cretaceous planktonic zoning used in this report. Table 2 gives the location and interval of all the Paleogene planktonic zones at each site. The representative faunas are listed in the Hole Summaries.

\section{SHALLOW WATER LIMESTONE}

In situ shallow-water carbonates of probable late Albian-early Cenomanian age were recovered from the Campeche Embankment at Sites 86, 94, and 95. Reworked sediments of this age were also found in the deep-water early Cenomanian (Rotalipora greenhornensis Zone) of Site 97. Based on evidence from these cores, the shallow water carbonates recovered are probably late Albian-early Cenomanian in age (Applin and Applin, 1965; Conkin and Conkin, 1956, 1958; Bonet, 1956).

Numerous specimens of Nummoloculina heimi were observed in Site 94 Cores 37 and 39. Large, free specimens of this shallow-water foraminifer are present in Core 37, and embedded specimens of $N$. heimi and Cuneolina species are present in Core 39 (Plate 5). Mr. R.H. Waite and Dr. C.C. Rust of the Shell Exploration and Development Research group agree that the $N$. heimi and Cuneolina species are of probable late Albian age. They also found that specimens of Dicyclina sp., believed to be a Cenomanian marker fossil, are present in Section 1 of Core 39, 67-69 $\mathrm{cm}$ above the aforementioned species (Plate 5).

Cores 19-22, Site 95 , contain partially dolomitized shallow-water limestone. Embedded miliolids were observed in Core 21, and rare free ostracod carapaces and embedded miliolids were found in Core 19. Poor recovery and dolomitization of most of the carbonate sediments recovered from Site 86, Cores 10-14 reduces the chance for 


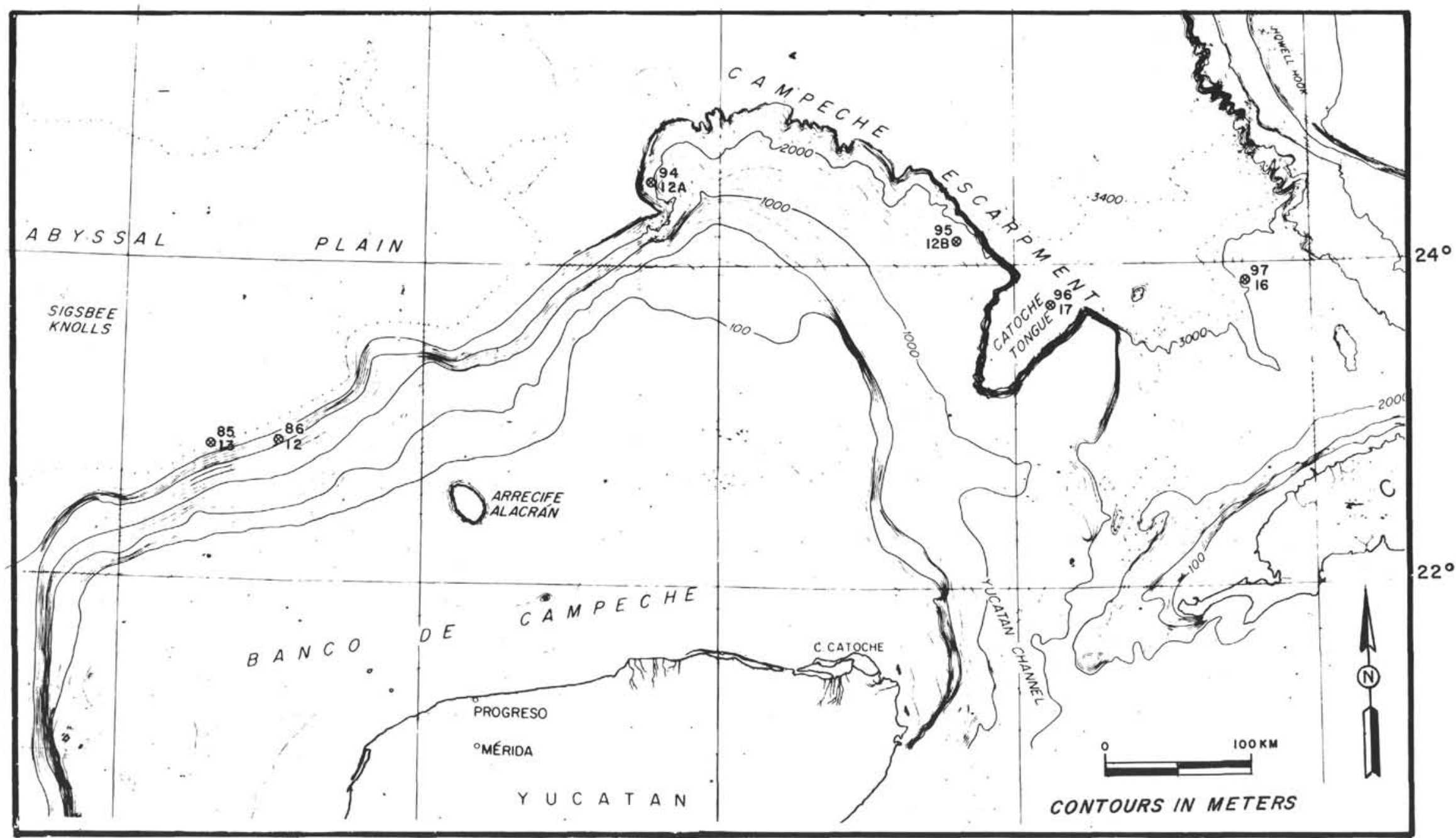

Figure 1. Index map, Campeche Embankment area, showing location of holes. 
TABLE 1

Cretaceous Planktonic Zonation Used

\begin{tabular}{c|l|l}
\hline \multicolumn{2}{c}{ Age } & \multicolumn{1}{c}{$\begin{array}{c}\text { Planktonic Zones (after Postuma, } \\
1964)\end{array}$} \\
\hline \multirow{4}{*}{ Maestrichtian } & Late & Abathomphalus mayaroensis \\
\cline { 2 - 3 } & Middle & Globotruncana gansseri \\
\cline { 2 - 3 } & Early & Globotruncana lapparenti tricarinata \\
\hline \multirow{3}{*}{ Campanian } & Late & Globotruncana calcarata \\
\cline { 2 - 3 } & Early & Globotruncana elevata \\
\hline \multirow{2}{*}{ Santonian } & Late & Marginotruncana carinata \\
\cline { 2 - 3 } & Early & Marginotruncana concavata \\
\hline Coniacian & & Marginotruncana schneeganzi \\
\hline Turonian & & Marginotruncana helvetica \\
\hline \multirow{3}{*}{ Cenomanian } & Late & Rotalipora cushmani \\
\cline { 2 - 3 } & Early & Rotalipora greenhornensis \\
\cline { 2 - 3 } & & Rotalipora appenninica \\
\hline
\end{tabular}

accurate identification of the fauna contained in this sediment. However, the miliolids and ostracod fragments present do indicate a shallow-water environment of deposition.

In the Straits of Florida, and abundance of shallowwater limestone rubble containing Nummoloculina heimi, reworked into late early Cenomanian (Rotalipora greenhornensis Zone) pelagic sediments, was encountered in Cores 6 through 10, Site 97. This treworked material must therefore have been deposited, partially cemented, and subjected to erosion by no later than earliest Cenomanian time.

It appears that shallow-water, miliolid-ostracod-bearing carbonates contributed to the construction of a vast, slowly subsiding platform at least to the close of Albian time in the Campeche Embankment area. As far as anyone knows, this carbonate platform could have encompassed a much larger area of the Gulf of Mexico than it does now. No paleontological evidence was recorded on Leg 10 which would indicate proximity to a deep-water Albian Sigsbee Deep or Florida Strait. The shallow-water carbonates recovered from Sites 86,94 , and 95 do suggest deposition in a fairly low energy interior platform environment.

It was planned that, on Leg 10, sediments of Albian age and older would be cored in the Sigsbee Deep and possibly in the Straits of Florida. Mechanical difficulties and time limitations prohibited the accomplishment of this undertaking. Debate concerning the origin of the deep Gulf of Mexico will continue until these sediments can be cored.

\section{CENOMANIAN}

The oldest planktonic fauna recovered is in Core 12, Site 97. This core contains abundant, well-preserved planktonic foraminifera which can be assigned to the Rotalipora appenninica Zone (earliest Cenomanian). An unlithified argillaceous, buff-colored lime mud in Section 1 of Core 12 yielded Rotalipora evoluta, $R$. appenninica, Praeglobotruncana delrioensis, Hedbergella planispira, $H$. amabilis, Globigerinelloides caseyi, and $G$. bentonensis. Shackoina sp. cf. $S$. multispina is rare in this assemblage. The presence of Rotalipora evoluta and Praeglobotruncana delrioensis, both of which have their evolutionary first occurrence at the base of the Cenomanian, along with the absence of Rotalipora greenhornensis, indicates that these sediments are of earliest Cenomanian age. The great abundance of planktonic foraminifera suggests deposition in the bathyal realm. Above this soft sediment there are lithified dolomitic limestones (Cores 11 and 12). Recrystallization of the embedded fossils in these two cores makes identification difficult.

In the overlying sediments (Cores 6-10), there is a planktonic foraminiferal association which represents the late early Cenomanian Rotalipora greenhornensis Zone. These sediments contain an admixture of abundant reworked shallow water miliolid limestone rubble (with Nummoloculina heimi). Planktonic foraminifera recovered from Cores 6 through 10 include Rotalipora greenhornensis, $R$. evoluta, Praeglobotruncana delrioensis, $P$. stephani, Hedbergella washitensis, $H$. planispira, $H$. amabilis, $H$. delrioensis, Planomalina buxtorfi, Globigerinelloides bentonensis, and $G$. caseyi. Preservation of these fossils is very good. The evolutionary first occurrence of Rotalipora greenhornensis is by definition at the base of the Rotalipora greenhornensis Zone. R. evoluta and Hedbergella washitensis become extinct in the Rotalipora greenhornensis Zone. the concurrence of these three planktonic species indicates a late Early Cenomanian age for this sediment. The presence of Planomalina buxtorf $i$ in these samples is considered noteworthy inasmuch as some authors place its extinction level in either latest Albian or earliest Cenomanian.

At Site 97, approximately 41 meters of sediment were drilled below Core 5 and above Core 6 . Core 5 contains a late Eocene pelagic fauna. Core 6 contains early Cenomanian sediment with late Eocene as well as early Eocene contamination. Late Cenomanian through late Paleocene sediments (Rotalipora cushmani Zone through Globorotalia pseudomenardii Zone) were not observed in situ or as contaminant in Core 6 , which indicates a hiatus is present at this location. It is not known at this time whether this apparent hiatus is local or regional.

Reworked late Cenomanian planktonic foraminifera were recovered from Hole $85 \mathrm{~A}$ at the base of the presentday Campeche scarp in the Sigsbee Deep. In Core 2, rare well-preserved specimens of Rotalipora cushmani and $R$. greenhornensis were found with a rich Late Pleistocene cool-water fauna (probably Illinoian). Reworked planktonic foraminifera probably of Coniacian age, including Marginotruncana sp. cf. M. schneegansi, $M$. renzi and Globotruncana lapparenti, were also present in this sample.

The white color and good test preservation of these reworked specimens indicate that they have not been reworked from any of the localities bordering the Gulf of Mexico where they have previously been reported. It is also apparent that these specimens have not been distorted by compaction and are not far removed from their original site of deposition. Sites 86, 94, and 95, drilled on the nearby Campeche Embankment, are devoid of Late Cenomanian sediments. The interpretation is, therefore, that the Campeche Embankment remained structurally high, receiving no deep water sediments, during 
TABLE 2

Leg 10 Paleogene Zone-Sample Index

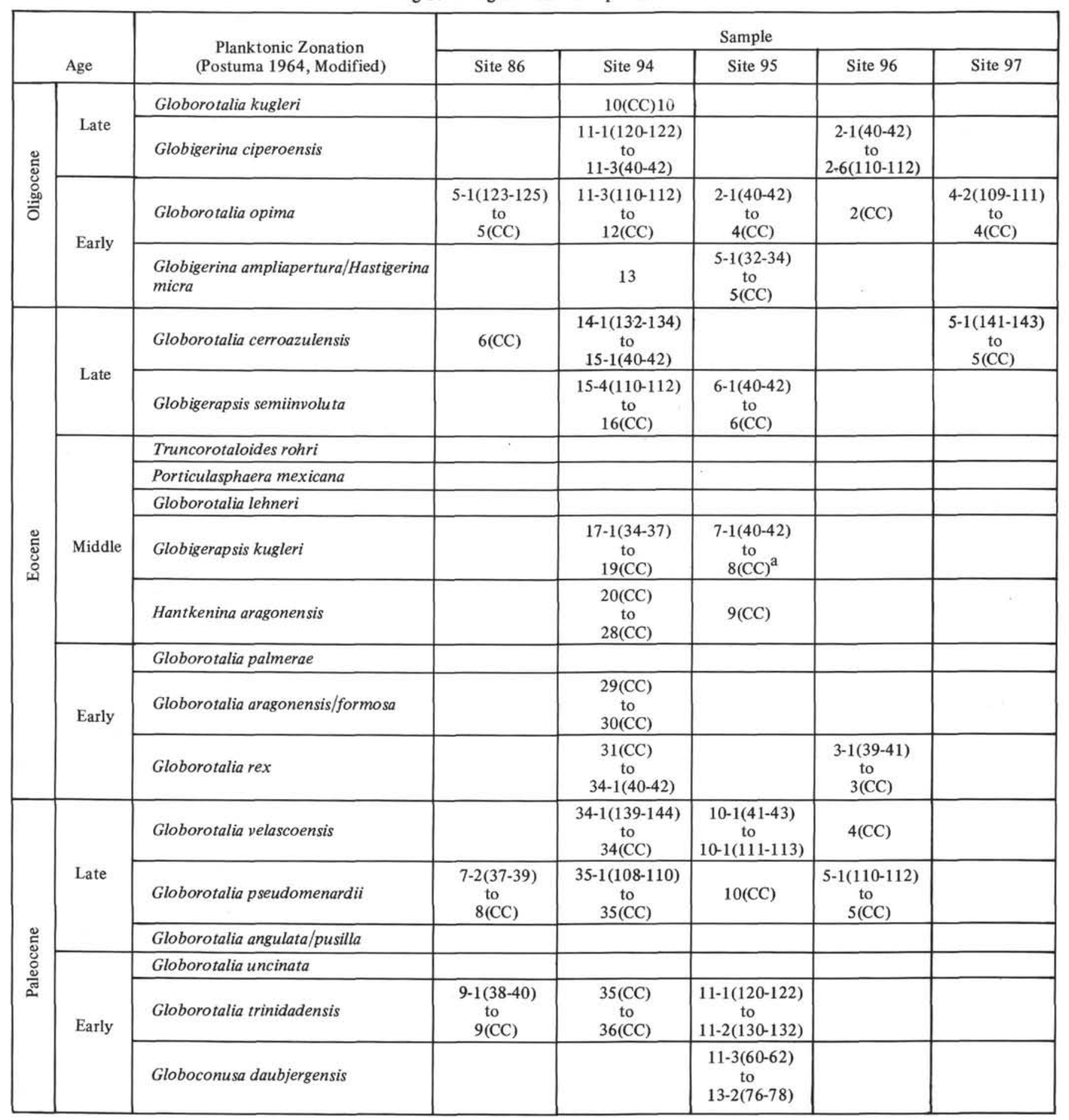

${ }^{\mathrm{a}}$ May be Hantkenina aragonensis Zone.

Cenomanian time while subsidence occurred in the Sigsbee Salt Basin and north of Cuba (in the vicinity of Site 97). It is possible that bathyal sedimentation began within the confines of the Sigsbee Salt Basin during the early Cenomanian (just as at Site 97) and continued through Cretaceous time. These pelagic sediments may have been exposed to submarine erosion after formation of the Sigsbee Knolls. More Drilling of the knolls is needed to answer this question.

As stated earlier, reworked miliolid limestone rubble and specimens of Nummoloculina heimi which are found in the early Cenomanian of Site 97 (Core 6-10), indicate 
that this limestone had already been deposited and partially cemented by no later than the earliest Cenomanian and probably by the close of the Albian. It also indicates that subsidence in the vicinity of Site 97 (possibly block faulting) occurred at least by the earliest Cenomanian and suggests that this area was proximate to topographically higher areas where the shallow-water limestones were exposed to erosion.

Site 97 was drilled into sediments underlying the present-day channel leading into the southeastern Gulf of Mexico. Deep-water sediments of early Cenomanian age were penetrated, but it has not been established that this sediment (Cores 6-12) indicates a Cenomanian channel into a Gulf basin. No holes have been drilled in the east central Gulf to verify deep water sedimentation of this age there. Since Site 97 is close to the Cuban mainland $( \pm 58$ miles), it is possible that the early Cenomanian geologic history, as recorded from Site 97, is more closely related to geologic events in the Cuban Salt Basin than to those of the central Gulf deep (exclusive of the Sigsbee Salt Basin). Late Cenomanian-Late Paleocene sediments are apparently absent at this location. Any attempt to interpret the meaning of this hiatus based on present information would be premature since current action, slumping, faulting, uplift, or other mechanisms may have been involved. The questions of when and if Yucatan and Florida were joined and whether or not there was an early Cenomanian channel into the southeastern Gulf await the coring of the $5 \mathrm{~km} / \mathrm{sec}$ layer north of Site 97 in the eastern portion of the Sigsbee Deep.

\section{TURONIAN-CONIACIAN}

In situ Turonian or Coniacian planktonic faunas were not recovered on Leg 10. As mentioned in the preceding paragraphs, rare pelagics probably of Coniacian age were found reworked into sediments of Pleistocene age in Hole $85 \mathrm{~A}$ in the Sigsbee Deep.

It seems likely that the Campeche Embankment area remained high during this period. The age of the shallow water limestone with Nummoloculina heimi is fairly well established from the reworked material from Site 97 (late Albian-early Cenomanian). Since it is overlain by early Paleocene pelagic sediments at Sites 86 and 94, and by early Santonian in Hole 95, it can be assumed that this limestone continued to be high and exposed to subaerial erosion during Turonian and Coniacian time.

The apparent absence of Turonian through Coniacian pelagic sediments at Site 97, in the present day Straits of Florida, detracts from the hypothesis that the channel has been in its present location since at least Albian time. The argument for removal or nondeposition of pelagic sediment during specific periods of geologic time and at specific geographical localities due to submarine currents should receive particular attention in this case. However, removal of all sediments ranging in age from late Cenomanian to early Eocene at Site 97 via this mechanism seems unrealistic. It is obvious that no conclusion or valid interpretation of the missing section at this location can be made without additional coring in this area.

\section{SANTONIAN}

Pelagic oozes of early and probable late Santonian age (Marginotruncana concavata and $M$. carinata Zones) were recovered from Site 95 on the northeast edge of the Campeche Embankment. Cores 15 through 18 contain an abundant, and for the most part well-preserved, planktonic foraminiferal fauna. The Santonian at this location overlies shallow-water miliolid limestone probably of late Albian-early Cenomanian age, and is overlain by pelagic oozes of early Campanian age. Bathyal deposition is indicated for the Santonian sediments at this site. During Leg 10, pelagic sediments of this age were not encountered at any other site.

Samples from Sections 1, 2, and 3 of Core 16, and Section 5 of Core 17 contain the following pelagic foraminifera: Marginotruncana concavata, $M$. carinata, M. renzi, $M$. angusticarinata, $M$. coronata, $M$. pseudolinneiana, Globotruncana lapparenti, Whiteinella spp., Heterohelix spp., Hedbergella spp., and Globigerinelloides spp. Benthonics include Heterostomella sp. cf. H. austinana, Gyroidina spp., and Gaudryina spp. Section 6 of Core 17 (111-113 cm), the core catcher of Core 17, and the core catcher of Core 18 contain the same pelagic fauna listed above, but with the addition of Marginotruncana sigali. The presence of $M$. concavata in Cores 16 through 18 indicates an early Santonian age for this interval $M$. renzi and $M$. sigali reach their extinction level during the early Santonian.

Probable late Santonian sediments were found in all samples examined from Core 15. This interval is distinguished from early Santonian by the absence of Marginotruncana concavata and from the early Campanian by the absence of Globotruncana stuartiformis and G. elevata. Although rare, small specimens of $M$. concavata along with rare specimens of $M$. sigali were found in this core, they appear to be reworked and the actual early Santonian-late Santonian contact is probably in Section 1 of Core 16. Planktonic foraminifera, which are abundant throughout Core 15, include Marginotruncana carinata, M. angusticarinata, M. coronata, G. lapparenti, G. fornicata, Whiteinella spp., Heterohelix sp. cf. H. reussi, "Gublerina" decoratissima, and Globigerinelloides sp. cf. G. yaucoensis. Benthonic foraminifera, which constitute a minor fraction in the samples examined, include Stensioina americana, Heterostomella austinana, and Gaudryina spp.

The fact that early Santonian pelagic oozes overlie shallow-water carbonates, probably of late Albian-early Cenomanian age, at Site 95 indicates that rapid subsidence began there during early Santonian time. These oozes are believed to have been deposited in a channel (possibly the original channel) into the southeastern Gulf of Mexico. Block faulting of the platform during early Santonian time could have formed the suggested trough.

Site 94 on the Campeche Embankment was continuously cored across the Cretaceous-Tertiary boundary. Late Cretaceous pelagic sediments were not recovered from this site. After coring basal Paleocene pelagic sediments, shallow-water late Albian to early Cenomanian carbonates were encountered. Site 86 , southwest of Site 94 
and also on the Campeche Embankment, was also drilled across the Cretaceous-Tertiary boundary. Cores above and below the contact indicate that this hole is probably devoid of late Cretaceous pelagic sediment. Apparently the early Paleocene overlies the shallow-water late Albianearly Cenomanian carbonates just as at Site 94. Based on these data, it seems reasonable to conclude that while a channel was forming to the east the northern portion of the Campeche Embankment remained high. The absence of Santonian pelagic sediments in areas such as these tends to rule out eustatic sea level rise during this period.

\section{CAMPANIAN}

Pelagic sediments of Campanian age were also recovered from Site 95. Sediments of this age were not penetrated in any other location cored during Leg 10. The early Campanian at Site 95 overlies pelagic sediments of late Santonian age. It is overlain by middle to late Maestrichtian pelagic sediments. The first observed in situ early Campanian planktonic foraminifera were contained in a sample from Section 3, Core 13. The sample, at 145-147 $\mathrm{cm}$, yielded a rich fauna (Globotruncana elevata Zone) which includes Globotruncana stuartiformis, G. elevata, $G$. lapparenti, G. fornicata, G. bulloides, Marginotruncana angusticarinata, M. carinata, Pseudotextularia elegans, Planoglobulina glabrata, and Globigerinelloides sp. cf. G. yaucoensis. Included in the relatively minor benthonic assemblage are common specimens of Stensioina americana, Gaudryina spp., and Anomalina sp. In Section 4 of Core $13(40-43 \mathrm{~cm}$ and $116-118 \mathrm{~cm})$, in the core catcher of Core 13 , and Section 1 of Core $14(120-122 \mathrm{~cm})$, the same abundant planktonic fauna is present. The core catcher sample from Core 14 contains a rich early Campanian planktonic fauna which consists, in part, of Globotruncana stuartiformis, G. elevata, G. lapparenti, G. fornicata, G. carinata, Marginotruncana angusticarinata, M. coronata, M. carinata, Planoglobulina glabrata, Globigerinelloides sp. cf. G. prairiehillensis, and Heterohelix spp. Benthonics include Stensioina americana, Heterostomella sp. and Gaudryina spp.

The presence of Globotruncana stuartiformis and $G$. elevata, which have their evolutionary first occurrence in the early Campanian ( $G$. elevata Zone), together with Marginotruncana angusticarinata and $M$. carinata, which become extinct in the early Campanian, indicates an early Campanian age for this interval.

Late Campanian sediments are not present in situ at Site 95 . They were probably deposited in the vicinity, but, apparently, subsequent slumping, or other mechanical processes operative in this area during late Maestrichtian time, resulted in the mixing of late Campanian sediments with a Maestrichtian planktonic assemblage. Globotruncana calcarata, which is restricted to the late Campanian, was observed reworked into a middle-late Maestrichtian fauna in Section 3 of Core $13(58-60 \mathrm{~cm})$. Globotruncana ventricosa and $G$. linneiana, probably reworked from the late Campanian but possibly from the early Maestrichtian, are also present in this sample.

The Campeche Embankment, at least in the areas of Sites 86 and 94, where the probable Albian-early Cenomanian shallow-water limestone is overlain by bathyal
Paleocene sediments, appears to have remained topographically high, receiving no sediments during Campanian time. In the vicinity of Site 95 , bathyal sedimentation, which was initiated during Santonian time, continued. Campanian sediments were not recovered from Site 97.

\section{MAESTRICHTIAN}

Planktonic foraminifera of middle-late Maestrichtian age (Globotruncana gansseri and Abathomphalus mayaroensis Zones) were found at Site 95. Samples from Section 3 of Core $13(27-29 \mathrm{~cm}$ and $58-60 \mathrm{~cm})$ show dilution of this pelagic fauna with abundant reworked planktonic foraminifera. In the sample at $27-29 \mathrm{~cm}$, one specimen of Globotruncana contusa (middle-Late Maestrichtian age) was noted in a reworked Santonian pelagic ooze. The sample below, at $58-60 \mathrm{~cm}$ of Section 3, contains a fairly rich middle-Late Maestrichtian planktonic assemblage with reworked Late Campanian-Early Maestrichtian pelagic foraminifera. Middle-Late Maestrichtian planktonics observed in this sample include Globotruncana contusa, $G$. sp. aff. G. gansseri, G. gagnebini, Pseudotextularia deformis, $P$. intermedia, Racemiguembelina fructicosa, Pseudoguembelina excolata, and Rugoglobigerina rotundata. Fossils found commonly in the middle Maestrichtian, but which are possibly reworked in this sample, (evolutionary first occurrence prior to middle Maestrichtian) include Globotruncana stuartiformis, G. fornicata, Globotruncanella havanensis, Planoglobulina multicamerata, and Pseudotextularia elegans. Forms present which definitely became extinct prior to the middle Maestrichtian include Globotruncana calcarata, G. ventricosa, and G. linneiana.

Bethonic foraminifera are prevalent in all samples examined from Section 2 of Core 13. Included are Bolivina incrassata, Bolivininoides trinitatensis, Bulimina taylorensis, Stensioina americana, and Marssonella sp. cf. M. oxycona. Species of Clavulinoides, Anomalina, Gyroidina, Robulus, and Cibicides are also present. It is probable that some of the benthonics observed are reworked.

Three samples examined above $110 \mathrm{~cm}$ in Section $2(76-78 \mathrm{~cm}, 40-42 \mathrm{~cm}$, and $11-13 \mathrm{~cm}$ ) contained minute specimens of early Paleocene globorotalids and globigerinids. Two samples examined from the lower part of Section $2(110-112 \mathrm{~cm}$ and $147-149 \mathrm{~cm})$ do not contain early Paleocene planktonic foraminifera. Therefore, based on this evidence, the Cretaceous-Tertiary contact is believed to fall above $110 \mathrm{~cm}$ and below $78 \mathrm{~cm}$ in Section 2 .

Since Maestrichtian pelagic sediments were not found at Sites 86 or 94, it is assumed that the northern Campeche Embankment was still topographically high at the close of Cretaceous time. It is considered possible that sedimentation continued across the Cretaceous-Tertiary boundary in the vicinity of Site 95. Specimens of Abathomphalus mayaroensis (planktonic indicator for the latest Maestrichtian) have not been observed to date, but planktonics such as Racemiguembelina fructicosa and Globotruncana contusa (which range through the Abathomphalus mayaroensis Zone) have been observed. Site 97 , in the Straits of Florida, is apparently devoid of sediment of this age. 


\section{PALEOGENE}

Paleontological data pertinent to this part of the stratigraphic column are found on Table 2.

The Paleogene sediments recovered from the Campeche Embankment area are pelagic oozes and indicate a bathyal locus of deposition. Good to excellent preservation of the foraminiferal tests was noted in all samples examined. Data of particular biostratigraphic importance were recorded at Sites 86 and 94, located on the northern portion of the Campeche Embankment, and at Site 95, located on the northeastern flank of the embankment. Sites 86 and 94 contain early Paleocene (Globorotalia trinidadensis Zone) pelagic oozes overlying shallow water carbonates of late Albian-early Cenomanian age. Inundation of the shallow-water carbonate sediments, which apparently had been exposed since late Albian to earliest Cenomanian time, occurred at the beginning of the Tertiary. Data from Site 94, where pelagic oozes are in direct contact with the shallow-water carbonate (continuously cored), indicate that the subsidence was rapid, if not catastrophic. Block faulting at the beginning of Tertiary time may have been responsible for this inundation.

At Site 95, the biogenic early Paleocene (Globoconusa daubjergensis Zone) sediments overlie middle to late Maestrichtian pelagic oozes with an apparently gradational Cretaceous-Tertiary contact in evidence. Further study of Section $2(11-78 \mathrm{~cm})$ in Core 13 may reveal a basal Paleocene pelagic foraminiferal zone, not previously recognized in the Gulf Region.

Two hiatuses, believed to be significant, were noted in the Paleogene on the Campeche Embankment. One of these stratigraphic breaks (Site 94, Core 35, core catcher) shows the late Paleocene Globorotalia pseudomenardii Zone pelagic sediments in contact with pelagic sediments of the early Paleocene Globoratalia trinidadensis Zone. Sediments representative of the Globoratalia angulata/pusilla and the Globoratalia uncinata zones are absent. This hiatus is believed to exist at Sites 86 and 95, although the actual contacts were not cored. An attempt to explain this phenomenon based on present data would be premature.

Evidence of another hiatus on the Campeche Embankment, where most of the middle Eocene is apparently absent, was found at Site 94. Between Core 16 (core catcher) and Core 17, Section $1(34-37 \mathrm{~cm})$, pelagic sediments of the late Eocene Globigerapsis simiinvoluta Zone and the early middle Eocene Globigerapsis kugleri Zone are seemingly in contact. The Truncorotaliodes rohri, Porticulasphaera mexicana, and Globorotalia lehneri zones are absent; these planktonic zones were not observed in any of the cores taken during Leg 10.

As stated previously, at Site 97, sediments ranging in age from early Cenomanian through late Paleocene were not observed and are apparently absent. Early Eocene planktonics, which are derived from the \pm 41 meters of sediment drilled below Core 5, were found as contaminants in Core 6 (early Cenomanian, Rotalipora greenhornensis Zone).

\section{SUMMARY}

No all-inclusive statement can be made concerning the Mesozoic through Paleogene biostratigraphy of the Campeche Embankment area. Leg 10 core data, however, suggest that block faulting may have been one of the important mechanisms responsible for the divergent sedimentary modes of deposition. Discontinuities, where pelagic sediments of varying ages overlie shallow-shelf carbonates, give a clue as to when the rapid subsidence of these blocks occurred. For example, it is now known that bathyal depths had been attained in the vicinity of Site 97 by earliest Cenomanian time. Core data also show that Site 95 is located where bathyal sedimentation commenced during early Santonian time, and that at Sites 86 and 94, bathyal water depths were attained at the beginning of Tertiary time. This east-to-west pattern of rapid subsidence affecting discrete portions of the vast lower Cretaceous carbonate platform leads one to the conclusion that intermittent Cretaceous through early Tertiary tectonic movements and later Tertiary regional subsidence could be responsible for the sedimentary sequence revealed during Leg 10.

Major discontinuities within the pelagic Paleogene section, such as the missing middle Eocene and middle Paleocene sections, are not understood at the present time. Other missing units are probably attributable to slumping and sliding, poor core recovery, or to their having been drilled through when the spot coring technique was employed.

The most important questions concerning the genesis of the Gulf of Mexico were not answered. The shallowwater late Albian-earliest Cenomanian carbonate section cored at Sites 86, 94, and 95 appears to have been deposited in back-shelf areas of the platform. Whether or not this platform encompassed a portion of, or even most of, the present Sigsbee Deep is still an open question. Whether or not Florida and Yucatan were part of a continuous Lower Cretaceous platform is also left open to debate. Most importantly, even if the shallow-water carbonate platform did extend beyond the present day limits, nothing can be said of when and how the Sigsbee Deep formed.

\section{ACKNOWLEDGMENTS}

I am grateful to Shell Oil Company for affording me the opportunity to participate in Leg 10 and for assistance in preparation of this paper. I thank the following employees of Shell Development Company: Mr. Robert Scarborough for scanning electron microscope work, and Mr. R.H. Waite and Dr. C.C. Rust for assistance in the identification of shallow water Cretaceous benthonic assemblages.

\section{REFERENCES}

Applin, P.L. and Applin, E.R., 1965. The Comanche Series and associated rocks in the subsurface in central and south Florida. U.S. Geol. Survey Prof. Paper 447.

Bandy, O.L., 1964. Cenozoic Planktonic Foraminiferal Zonation. Micropaleontology. 10(1). 
Bonet, Federico, 1956. Zonificatión Microfaunística de las Calizas Cretácicas del Este de México. Asoc. Mexicana de Geólogos Petroleros Bol. 8.

Conkin, J.E. and Conkin, B.M., 1956. Nummoloculina in Lower Cretaceous of Texas and Louisiana. Am. Assoc. Petroleum Geologists Bull. 40(5).
1958, Revision of the genus Nummoloculina and emendation of Nummoloculina heimi Bonet. Micropaleontology. 4(2).

Postuma, J. A., 1964. Manual of Planktonic foraminifera: Unpublished Shell Rept. The Hague (Bataafse Internationale Petroleum Maatschappi) 2 vols. 

PLATE 1

Scanning Electron Micrographs

Figure $1 \quad$ Planomalina buxtorfi (Gandolfi). $74 \times 10-97-8(\mathrm{CC})$

Figure 2 Rotalipora evoluta Sigal. 124X 10-97-12-1

Figure 3 Praeglobotruncana stephani. (Gandolfi). 102X 10-97-8-1 (110-112)

Figure $4 \quad$ Hedbergella washitensis (Carsey). 102X 10-97-8-4 (110-112)

Figure 5 Praeglobotruncana delrioensis (Plummer). 145X 10-97-12-1 (110-112)

Figure 6 Rotalipora greenhornensis (Morrow). 86X 10-97-6(CC) 
PLATE 1
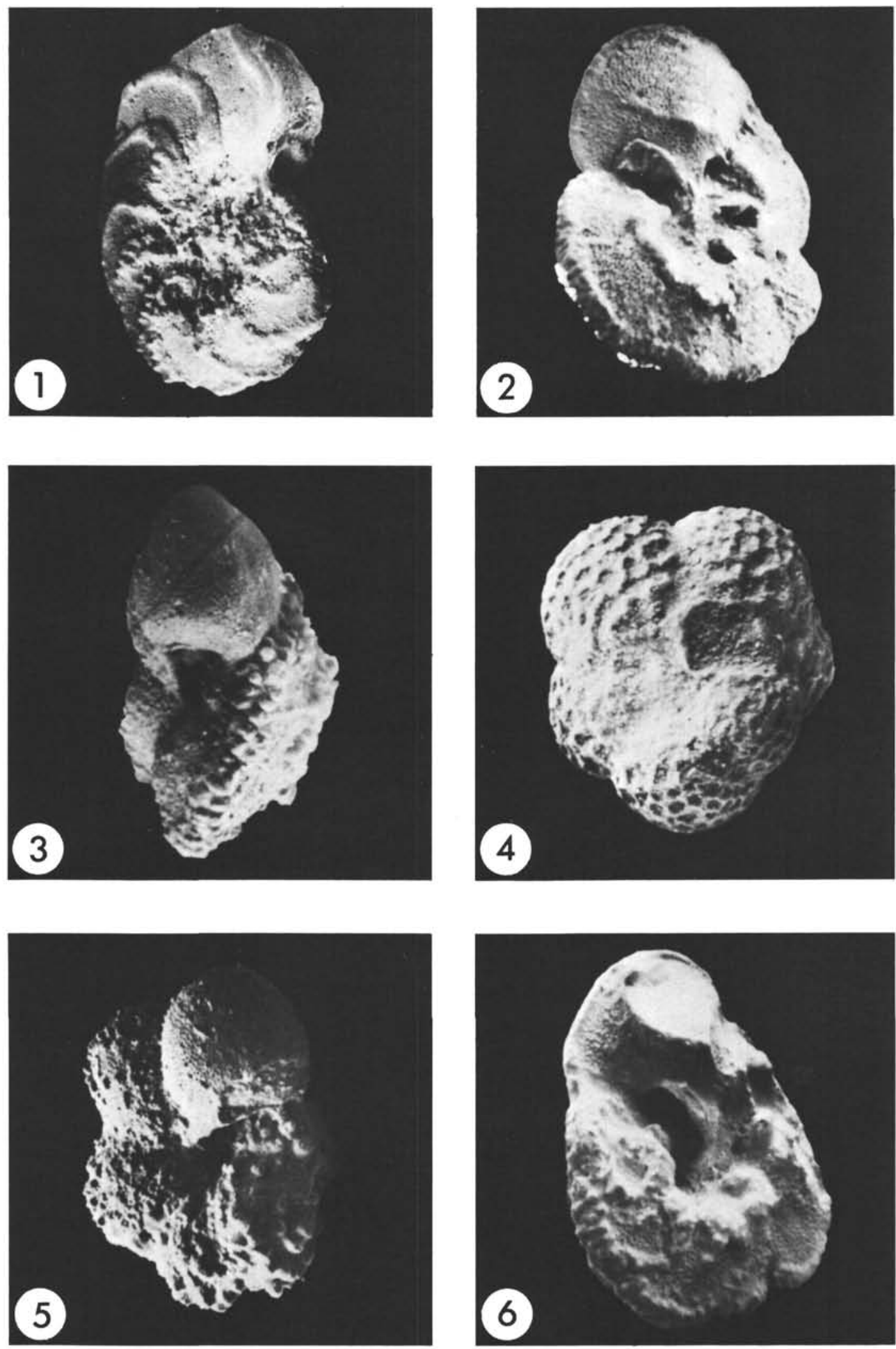


\section{PLATE 2}

Scanning Electron Micrographs

$\begin{array}{llllll}\text { Figure } 1 \quad \text { Marginotruncana sigali Reichel. } 62 \times & \text { 10-95-17-6 }\end{array}$ $(111-113)$

Figure 2 Marginotruncana angusticarinata (Gandolfi). 86X 10-95-16-1 (41-43)

Figure 3 Marginotruncana carinata Dalbiez. $68 \times 10-95-16-2$ $(112-114)$

Figure 4 Marginotruncana renzi Gandolfi. 91X 10-95-17-2 $(41-43)$

Figure 5,6 "Gublerina" decoratissima (de Klasz). E. 122X, F. $88 \times 10-95-15-4(112-114)$ 
PLATE 2
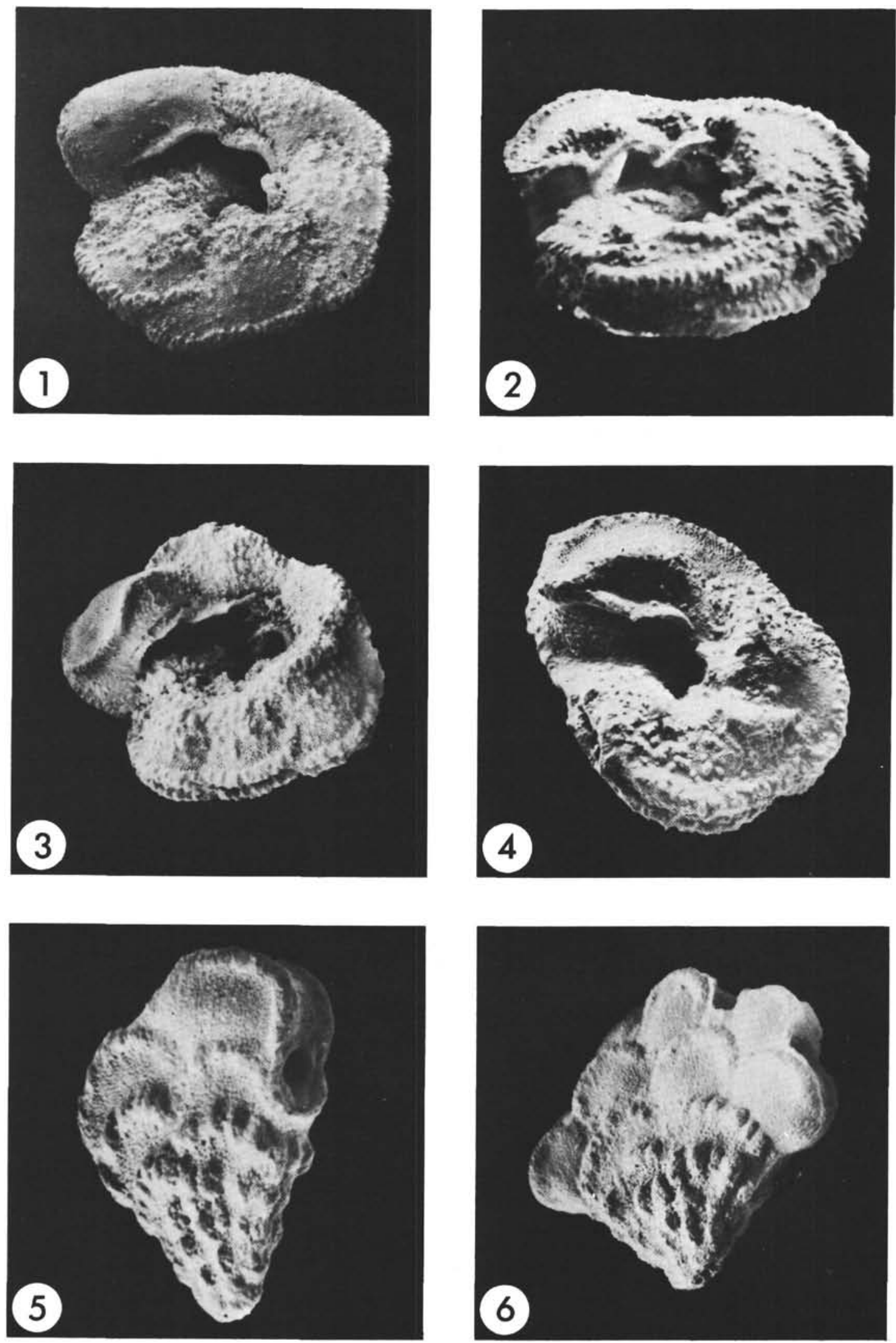


\section{PLATE 3}

Scanning Electron Micrographs

Figure 1 Planoglobulina glabrata (Cushman). $77 \times$ 10-95-14 (CC)

$\begin{array}{llll}\text { Figure } 2 & \text { Racemiguembelina fructicosa } & \text { (Egger). } 98 \times\end{array}$ $10-95-13-3(58-60)$

Figure 3 Globotruncana contusa (Cushman). 62X 10-95-13-3 $(58-60)$

Figure 4 Globorotalia trinidadensis Bolli. 145X 10-95-11-4 $(40-42)$

Figure $5 \quad$ Globorotalia pseudomenardii Bolli. 136X 10-86-7.5 (110-112)

Figure 6 Globorotalia velascoensis (Cushman). 101X 10-86-8-3 $(41-43)$ 


\section{PLATE 3}
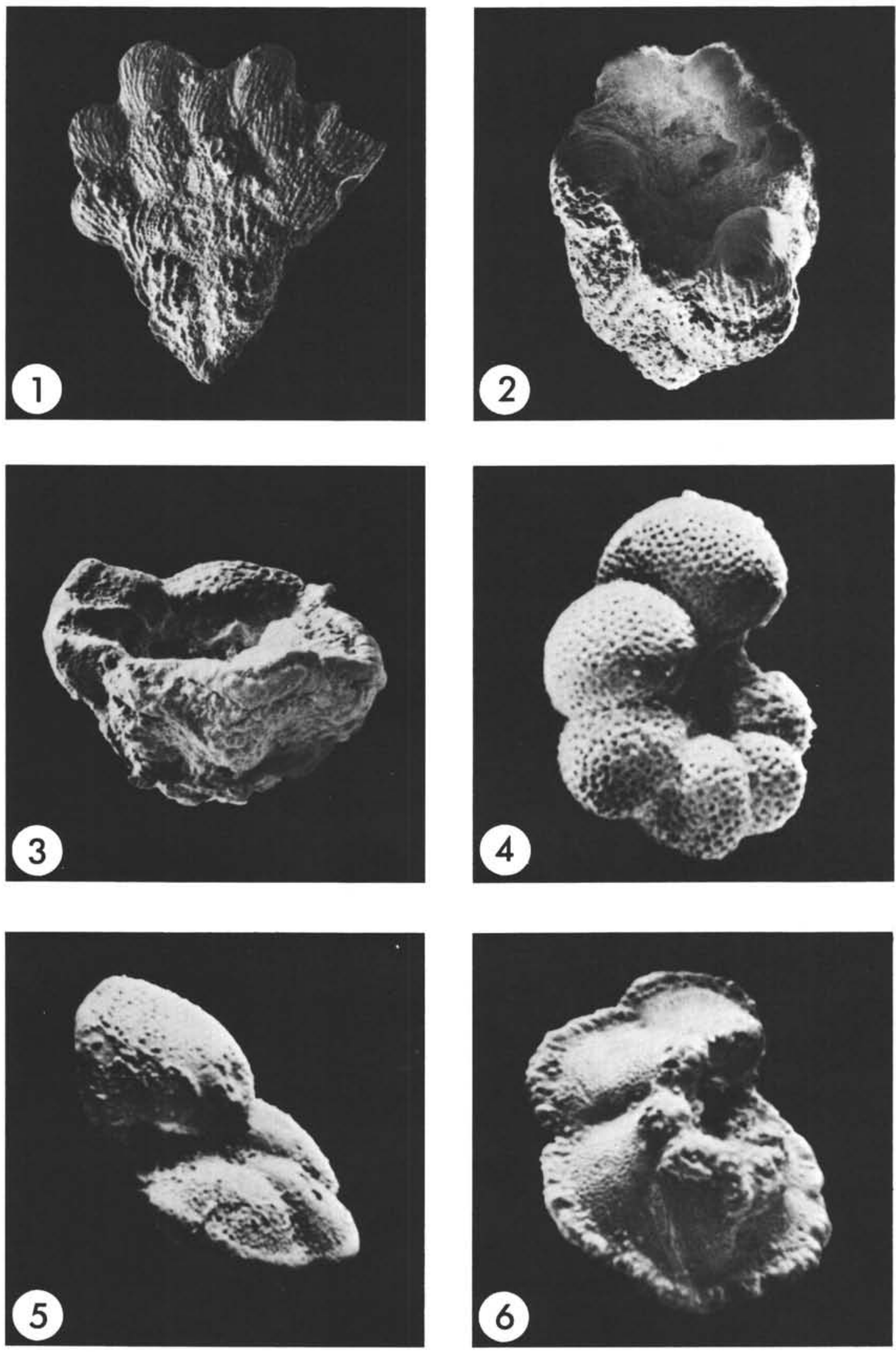
PLATE 4
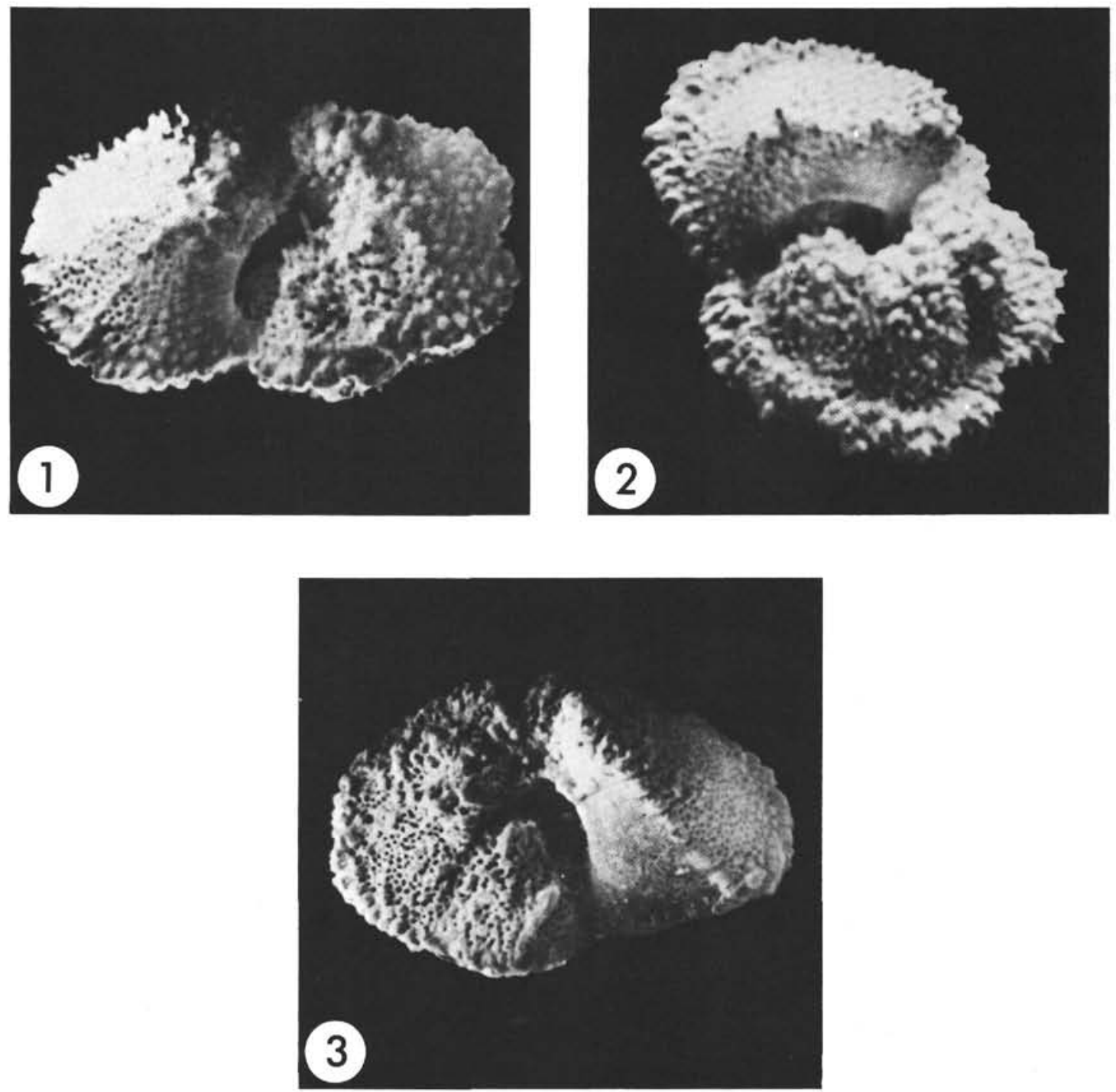

Scanning Electron Micrographs

Figure 1 Globorotalia aequa Cushman and Renz 116X 10-96-5-1 (110-112)

Figure 2 Globorotalia rex Martin 128X 10-96-3-2 (39-41)

Figure 3 Globorotalia aragonensis Nuttall $105 \times 10-94-23-2$ $(40-42)$ 
PLATE 5
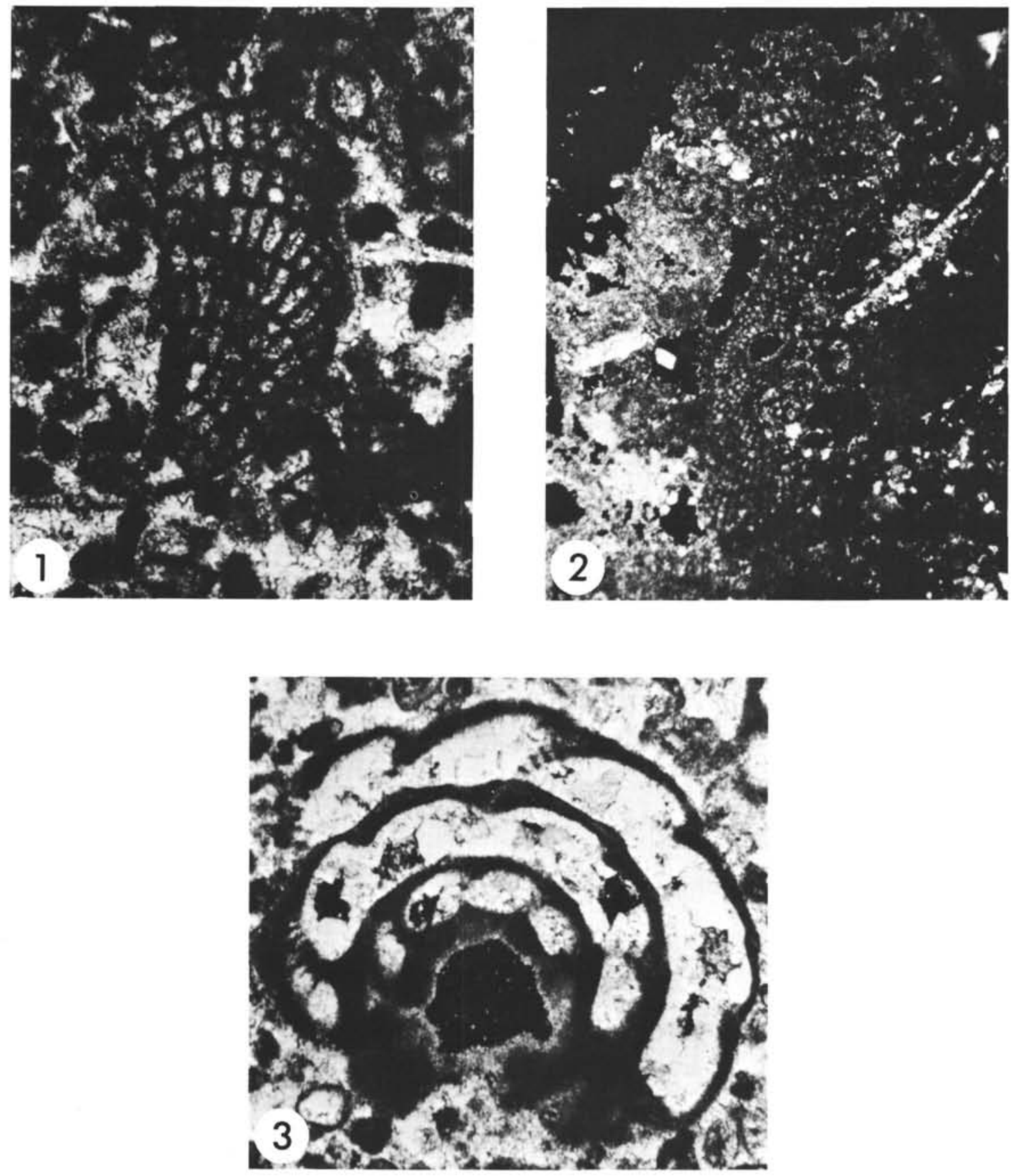

Figure $1 \quad$ Cuneolina sp. $60 \times 10-94-39$

Figure 2 Dicyclina sp. $25 \times 10-94-39-1$ (67-69)

Figure $3 \quad$ Nummoloculina heimi Bonet 51X 10-94-39 